Portland State University

PDXScholar

6-15-2018

\title{
Exploring Cap-and-Trade: a California Case Study
}

Madison Daisy Hathaway

Portland State University

Follow this and additional works at: https://pdxscholar.library.pdx.edu/honorstheses

Let us know how access to this document benefits you.

Recommended Citation

Hathaway, Madison Daisy, "Exploring Cap-and-Trade: a California Case Study" (2018). University Honors Theses. Paper 612.

https://doi.org/10.15760/honors.624

This Thesis is brought to you for free and open access. It has been accepted for inclusion in University Honors Theses by an authorized administrator of PDXScholar. Please contact us if we can make this document more accessible: pdxscholar@pdx.edu. 


\title{
Exploring Cap-and-Trade: A California Case Study
}

\author{
Madison Daisy Hathaway
}

An undergraduate honors thesis submitted in partial fulfillment of the requirements

for the degree of

Bachelor of Science

in

University Honors

and

Quantitative Economics

\author{
Thesis Adviser \\ Forrest Williams \\ Portland State Honors College
}

Spring 2018 


\section{Abstract}

Climate change is an urgent issue unlike anything humanity has ever faced. This thesis explores a market-based tool to reduce greenhouse gas emissions and limit global warming. Specifically, it uses the California cap-and-trade program as a case study. It provides background information on this program, which was established from the California Global Warming Solutions Act of 2006 (AB 32) and in 2017 was extended to 2030. Evaluating market-based tools is becoming increasingly important as countries and states look for ways to reduce climate pollution and create investments in a clean energy future. Through analysis of government reports and a literature review, this paper finds that the program is not performing at its optimum. It recommends reducing the number of allocated permits to increase the demand and the price. Additionally, it recommends implementation of processes that evaluate and reconsider how different programs created under $\mathrm{AB} 32$ can complement carbon pricing-not undermine its ability to reduce emissions. Although the California cap-and-trade program is not performing at its optimum, the program represents California's commitment to addressing climate change and acts as an international inspiration for climate action. There are multiple states that are currently considering implementing carbon pricing tools. This paper concludes by providing an overview of the pending carbon legislation in Oregon. 


\section{Table of Contents}

Abstract

Table of Contents 2

Introduction $\quad 4$

Climate Change $\quad 5$

Causes and Effects $\quad 5$

$\begin{array}{ll}\text { Global Response } & 6\end{array}$

United States’ Response $\quad 7$

California's State Action $\quad 8$

California Cap-and-Trade Program 99

General Overview of Cap-and-Trade 9

$\begin{array}{ll}\text { Program Features } & 10\end{array}$

$\begin{array}{ll}\text { Flexibility Mechanisms } & 11\end{array}$

$\begin{array}{ll}\text { Offsets } & 11\end{array}$

$\begin{array}{ll}\text { Banking } & 12\end{array}$

$\begin{array}{ll}\text { Price Collar } & 12\end{array}$

Auction Revenue 13

$\begin{array}{ll}\text { Concerns } & 13\end{array}$

Legal 13

$\begin{array}{ll}\text { Carbon Market } & 14\end{array}$ 
Renewable Portfolio Standards

Emissions Reductions 


\section{Introduction}

Climate change is the most pressing issue of our time. It is a threat to the very existence of life on earth. Even though it might seem like an insurmountable task, we must continue to do our best to mitigate the effects of climate change and get our world on a more sustainable path. Cap-and-Trade is a market-based tool that addresses climate pollution and creates revenue to invest in a clean energy future. The United States has a history of inaction at the federal level for issues related to climate change, but the world cannot afford to wait for federal legislation. Climate change is happening right now, and climate disasters will continue to worsen. For this reason, state action is necessary to reduce climate pollution and expand renewable energy capacity.

In this paper, I explore California's cap-and-trade program. I first discuss the need for strong climate policy in the United States and emphasize its urgency given our current set of environmental issues. A brief history of the international efforts to address climate issues is provided with reasons why it is important for individual states to take action given the current administration at the federal level. I provide a history of California's Global Warming Solutions Act (AB 32) of 2006 which established a cap-and-trade program in an effort to reduce climate change. I provide an overview of the general model of cap-and-trade programs and detail what facilities are impacted, the level of the emissions cap, and which gases are regulated under the bill. I then specify the features of the bill including the flexibility mechanisms, carbon permit trading, and how auction revenue is being used. I then detail the major concerns of the program including legal, market, renewable portfolio standards, emission reduction and environmental justice. I propose future considerations to improve the program and a brief argument for 
continuing the program. Lastly, I provide information on the pending carbon legislation in Oregon.

\section{Climate Change}

\section{Causes and Effects}

Scientific experts all around the world are concerned about the way that our climate is changing. In 2013, the Intergovernmental Panel on Climate Change (IPCC) published its Fifth Assessment Report. Their group of 1,300 independent scientific experts from countries all over the world concluded that there is a more than 95 percent probability that human activity over the past 50 years have warmed the planet. They attribute the main causes of the warming to greenhouse gas emissions that result from the combustion of fossil fuels such as petroleum (oil), natural gas, and coal. Additional sources of greenhouse gasses come from deforestation, changes in land use, soil erosion, agriculture and livestock (IPCC, 2013). When greenhouse gasses are released they warm the atmosphere.

The effects of global warming have been felt across the globe. The Environmental Protection Agency (EPA) highlights some of the most pressing issues on the "Climate Change Science" section of their website: changing temperature and precipitation patterns, increases in ocean temperatures, sea level, and acidity, melting of glaciers and sea ice, changes in the frequency, intensity, and duration of extreme weather events, shifts in ecosystem characteristics, like the length of the growing season, timing of flower blooms, and migration of birds, and increasing negative effects on human health and well-being (EPA, 2017).

The majority of global greenhouse gas (GHG) emissions come from energy-related carbon dioxide $\left(\mathrm{CO}_{2}\right)$ and methane $\left(\mathrm{CH}_{4}\right)$ emissions. The International Energy Agency (IEA) 
cites that $80 \%$ of global energy consumption is based on fossil fuels. In $2016,56 \%$ of US carbon emissions came from transportation and electricity. Similarly, in $201558 \%$ of California's carbon emissions came from transportation and electricity.

In the United States, the top source of carbon emissions in the energy sector is coal. According to a 2015 report by the U.S. Energy Information Administration (EIA), the total $\mathrm{CO}_{2}$ emissions resulting from U.S. electric coal power were 1,364 million metric tons. In contrast, $\mathrm{CO}_{2}$ emissions resulting from natural gas and petroleum were 530 million metric tons and 24 million metric tons, respectively. On the global market for energy, fossil fuels are favored. In the electricity sector, global subsidies to fossil fuels amount to about $\$ 100$ billion annually, while global subsidies to renewable forms of electricity amount to about $\$ 30$ billion annually (Kitson, Wooders and Moerenhout, 2011). Shifting to a low-carbon future will require these massive fossil fuel subsidies to diminish. This, however, has been a topic of conversation for decades and is not an easy ask.

\section{Global Response}

In 1992, the United Nations Framework Convention on Climate Change (UNFCCC) was established as an international environmental treaty at the Rio de Janeiro Earth Summit. In March 1994, the agreement went into force after a sufficient number of countries ratified it. A year later in 1995, parties to the UNFCCC meet in Berlin which served as the first Conference of Parties (COP) with the purpose of outlining specific targets on emissions. It wasn't until the 1997 Kyoto Protocol (COP 3) that those emission target goals were agreed upon. The United States never ratified the Kyoto Protocol did not uphold emission reduction commitments when the protocol went into effect in 2005. A decade later in 2015, the Paris Agreement (COP 21) aims to 
limit global warming to less than two degrees Celsius, with a major effort to limit the rise in temperature to 1.5 degrees Celsius.

\section{United States' Response}

To uphold the commitments made by the United States, President Obama and the EPA created the Clean Power Plan. The plan was the first of its kind to addresses climate issues and significantly reduce carbon and methane pollution from power plants. It introduced strong standards for power plants, and also customized goals for certain states. The customized goals take each state's energy mix into account but ensures that there is consistency across the nation and that all states are accountable. It was the big first step made by the United States in addressing climate change and demonstrated to international allies that the U.S. was serious about upholding its commitments made in the Paris Agreement.

On February 9, 2016, enforcement of the plan was stayed by the Supreme Court due to lower court rules involving pending lawsuits. The plan hit the courts again on September 27, 2016 in Washington where arguments were heard for over six hours of. Challengers of the law claimed the federal government overstepped its authority by regulating the energy industry, which is a significant portion of the U.S. economy (Templeton, 2016). Many of the states involved in the lawsuits use coal as their primary source of electric power generation, and this would subject them to a $32 \%$ emission reduction by 2030 .

The Paris Agreement went into effect on November 4, 2016, the same day Donald Trump won the electoral vote in United States 2016 presidential election. In June 2017, the Trump Administration announced their plan to pull out of the agreement November 4, 2020, as soon as is legally permissible. Later in October 2017, Trump began efforts to repeal the Clean Power 
Plan. Without legally binding targets, the United States is unlikely to meet the emission reductions promised in the Paris Agreement.

Donald Trump believes that the Paris Agreement, "would undermine our economy, hamstring our workers, weaken our sovereignty, impose unacceptable legal risks, and put us at a permanent disadvantage to the other countries of the world" (Trump, 2017). The administration's plan to pull out of the climate agreement is likely to be at the forefront of the 2020 Presidential election which takes place on November 3, 2020. If Trump is defeated by his Democratic opponent, they can make it clear to the world that regardless of what paperwork the Trump administration files to the United Nations on November 4, 2020 to exit the Paris Agreement, the United States will hold true to their commitments moving forward and remain in the agreement.

\section{California's State Action}

After the United States never ratified the Kyoto Protocol in 2005, the California State Legislature recognized the need for state leadership and passed the Global Warming Solutions Act of 2006, also known as Assembly Bill 32 (AB32). The bill created a comprehensive, multiyear program to reduce greenhouse gas (GHG) emissions and required the California Air Resources Board (CARB) to develop a plan to achieve the goal of reducing emissions to 1990 levels by the year 2020. As part of the strategy to meet these competitive emission reduction targets, California established a statewide cap-and-trade program that regulates facilities that emit over 25,000 metric tons of carbon dioxide equivalent (MTCO2eq) on an annual basis. When the program began in 2013, it regulated large industry and electric energy generators and in 2015 was expanded to regulate transportation fuels and natural gas. In 2016, the California Legislature passed senate bill (SB) 32 which codified a $2030 \mathrm{GHG}$ emission reduction goal of 40 percent 
below 1990 levels, as well as assembly bill (AB) 398, which extended the cap-and-trade program to 2030 .

\section{California Cap-and-Trade Program}

\section{General Overview of Cap-and-Trade}

Cap-and-Trade is a market-based tool that addresses climate pollution and creates revenue to invest in a clean energy future. To describe how cap-and-trade functions, I created two firms to use as examples: Firm A and Firm B. A cap is established within a given region. A cap is a restriction of how much total pollution may be emitted across all firms. The permissible level of pollution is then broken up into allowances, usually as a unit, one metric ton of carbon dioxide equivalent (MTCO2eq). Firm A and Firm B are both required to purchase allowances or permits from the government or another central authority in order to pollute. They are not allowed to pollute beyond that cap without additional permits acquired through trade with other firms. Innovation occurs if the cap is set low enough to cause the marginal cost of abatement to be higher than adopting newer and better technologies. This results in the least cost pollution abatement because firms abate pollution until their marginal cost of abatement is reached.

A firm's ability to reduce their emissions varies based on their capital and operational expenses. Thus, they have different costs associated with pollution abatement. If Firm A has lower capital and operational expenses and abates pollution to a level below the cap, it is authorized to sell the excess permits to other firms that were not able to reduce their emissions. Say Firm B was one such firm. Due to their higher marginal abatement costs it has incentive to purchase the excess permits from Firm A. It is important to note that Firm B still has incentive to figure out how to adopt newer and better technologies in the long run. Their pollution fees 
continue to increase which ultimately causes their marginal cost of abatement to be higher than adopting newer and better technologies.

\section{Program Features}

The California cap-and-trade program regulates the six gases covered by the Kyoto Protocol: carbon dioxide (CO2), methane (CH4), nitrogen dioxide (N2O), hydrofluorocarbons (HFCs), perfluorocarbons (PFCs), sulfur hexafluoride (SF6), plus nitrogen trifluoride (NF3), and other fluorinated greenhouse gases. So that the gasses can be compared, they are converted into metric tons of carbon-dioxide equivalents (MTCO2eq). In California, the cap is determined by the California Air Resources Board (CARB). They determine the cap as the total maximum amount of allowable emissions to be released by regulated facilities and parcels them into "allowances" or "credits." The credits then serve as units of emissions and determine the amount that a regulated entity is allowed to emit within a specific time frame.

Each year the cap becomes lower to encourage emission reductions. When the initial cap was set in 2013, it was set to 162.8 million metric tons of carbon-dioxide equivalents (MMTCO2eq), 2\% below forecasted emissions from 2012 and it only regulated large industry and electric energy generators. The 2015 cap was set at 394.5 MMTCO2eq, which was expanded to cover transportation fuels and natural gas. Since then, the cap has been declining annually by around 3\%. The 2020 limit 334.2 MMTCO2eq and the 2030 limit is 200.5 MMTCO2eq (C2ES, 2018). The green columns in Figure one illustrates this below. If a facility does not reduce its emissions to the limits set by CARB in time to meet the compliance deadline, the facility is required to pay for four allowances for every excess ton of greenhouse gases emitted. For example, if the facility emitted 50 tons of carbon dioxide above the maximum CARB allowed, 
the facility would be required to purchase 200 carbon credits to the price of auctioned credits and reduce emissions to targets set by the statute.

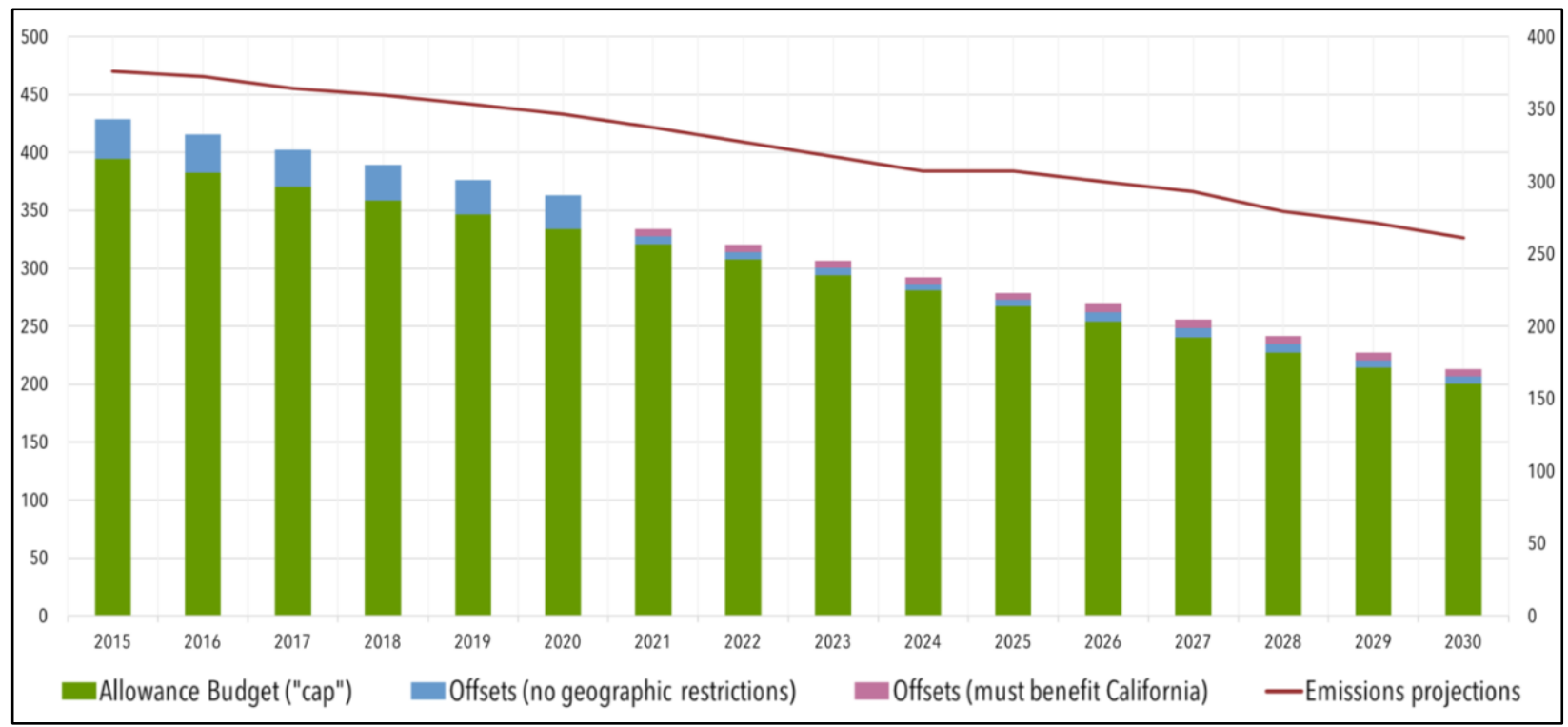

Figure 1: California's greenhouse gas emission cap and business-as-usual (BAU) projections. Courtesy of Center for Climate and Energy Solutions (C2ES)

\section{Flexibility Mechanisms}

\section{Offsets}

Offsets are a way for companies to comply with emission reduction requirements by investing in programs that reduce carbon emissions from sources that are not currently regulated under the cap, such as reforestation and methane reductions from livestock farms. Offset investments must be made in North America. Similar to the carbon cap, the offset allowances decline over time. In Figure 1, offsets are shown in blue and pink. The first five years of the program offer companies time to invest in technologies to reduce their emissions and provide offset options up to $8 \%$ of total compliance obligation. Starting in 2021, at least half the offsets used for compliance must come from investments that directly benefit California and the offset options until 2025 reduce significantly to $4 \%$. Between 2025 and 2030, 6\% total compliance 
obligation can come from offsets. This increase is to offer flexibility as the carbon cap reaches its lowest point.

\section{Banking}

Banking allows a facility that has excess allowances at the end of the year to "bank" the allowances to use in the years to follow. This essentially allows facilities to keep these allowances to use during years of increased output. The program makes it easier for facilities that may experience annual variations in the market and unexpected events like extreme heat or cool weather that increases the need for energy use. The credits that facilities bank do not expire, but CARB does limit the amount of banked allowances that a facility may hold based on the overall allowance budget of the facility.

\section{Price Collar}

The flexibility mechanisms in $\mathrm{AB} 32$ don't go without additional oversight. The California Legislature was concerned that the flexibility mechanisms would be taken advantage of, so they wrote in what they call a "price-collar." This collar sets a price floor and allows CARB to distribute some free allowances. The original assembly bill included a $\$ 10$-per- metricton price floor for auctions in 2012 and 2013. In 2014, the price floor started rising 5\% per year (plus inflation). The program also features an allowance price containment reserve which can be used to reduce permit prices if they become excessively high. This is achieved by CARB reserving $4 \%$ of all allowances. This containment reserve and the price floor give CARB more control over the market and allows them to be in a better position to predict emission reductions based on the set price of carbon permits. 


\section{Auction Revenue}

Revenue from the sale of permits is held in the Greenhouse Gas Reduction Fund (GGRF), controlled by the California Legislature and governor. It is up to these governing bodies to apportion funds from the GGRF during the annual budgeting process to the agencies and programs. In September of 2016, a report was released by the California Air Resources Board about California's climate investments. From the beginning of the program though the end of 2017, the GGRF has invested $\$ 4$ billion in sustainable communities and clean transportation, \$503 million in energy efficiency and clean energy, and \$765 million in natural resources and waste diversion. In 2018, \$284 million will be invested in community air protection.

\section{Concerns}

\section{Legal}

The program has been subject to a number of lawsuits. In 2012, California Chamber of Commerce filed a lawsuit claiming that cap-and-trade was legally a tax. In the state of California, taxes require a two-thirds majority of the legislature to pass (Ashton, 2017). In late June 2017 the suit was defeated, and the program was declared legally permissible (Megerian, 2017). Another lawsuit the program faced was brought forth by environmental justice advocates who were concerned about firms that are able to afford purchasing excess permits to pollute beyond their original facility cap would create pollution hot spots. Carbon pollution often is partnered with co-pollutants like nitrous oxide and particulate matter that are harmful to human health. Polluters are often located in marginalized communities where low-income people and people of color bear the brunt of the health burden. The suit, "Association of Irritated Residents v. California Air Resources Board," claimed that CARB did not adequately consider alternatives to cap-and-trade, like carbon taxes that do not create additional localized hotspots (Takade, 
2013). In 2012, the court ruled that held that CARB did not "disregard the law or act arbitrarily or capriciously in adopting the scoping plan" (California Court of Appeal, 2012).

\section{Carbon Market}

The carbon market has not created a strong demand for emissions credits. The LA times reported in June 2016 that "during the most recent auction in May [2016], only 11\% of the permits offered for sale were purchased" (Vartabedian, 2016). The article quotes Harry Horner who is an analyst for CaliforniaCarbon.info, a private entity that is hired to track emissions and price forecasts for the Western Climate Initiative. Horner said that, "the market is clearly in a position of cumulative surplus" (Vartabedian, 2016). Horner estimated there are 120 million excess permits, three times more than were up for sale at the latest auction. This shows that if emissions credits are valued at low prices, there is less incentive for facilities to reduce emissions. This results in credit auctions that bring in significantly less revenue than expected. The flexibility that emission banking provides is also a likely culprit. When unused emission credits rollover into subsequent auctions that are already experiencing surpluses, the issue is exacerbated.

\section{Renewable Portfolio Standards}

Renewable energy portfolio standards for the State of California were set around the same time the cap-and-trade program was developed. Energy Action Plan I went into law in 2006 and required electric utility companies to source at least $20 \%$ of their power from renewable energy sources by 2010. In 2008, Governor Arnold Schwarzenegger signed an executive order that mandated the standard be increased to 33\%. In addition to this Renewables

Portfolio Standard, the California Legislature also passed the Emergency Economic Stabilization Act in 2008. This provided $\$ 18$ billion in incentives for renewable energy and energy efficiency 
programs. One of the key features of this incentive package was tax cuts for solar panel installations, like the solar Investment Tax Credit (ITC) program. These and other environmental policies that California adopted are excellent at reducing greenhouse gas emissions. The problem is that when partnered with the cap-and-trade program, they mandate emissions reductions that are near the level of the cap. This causes a decrease in the demand for permits because many firms are already meeting that level of abatement.

\section{Emissions Reductions}

According to a 2016 report from CARB, "the total 2016 GHG emissions reported under MRR decreased by approximately 20.7 million metric tons of $\mathrm{CO} 2 \mathrm{e}$, or 4.8 percent, in comparison to 2015. Emissions that are covered by the Cap-and-Trade program decreased by approximately 16.4 million metric tons of CO2e, or 4.8 percent" (CARB, 2016). The report also states that, "in 2014, total GHG [greenhouse gas] emissions were 441.5 million metric tons of CO2 equivalent (MMTCO2e), a decrease of 2.8 MMTCO2e compared to 2013. This represents an overall decrease of 9.4\% since peak levels in 2004." However, as shown in Figure 2 below, the largest reductions came in 2009, before the cap-and-trade program went into effect and right in the midst of the global recession. This makes it unclear if the recession was the catalyst for emission reductions or if the programs established with $\mathrm{AB} 32$, particularly cap-and-trade, were effective. 


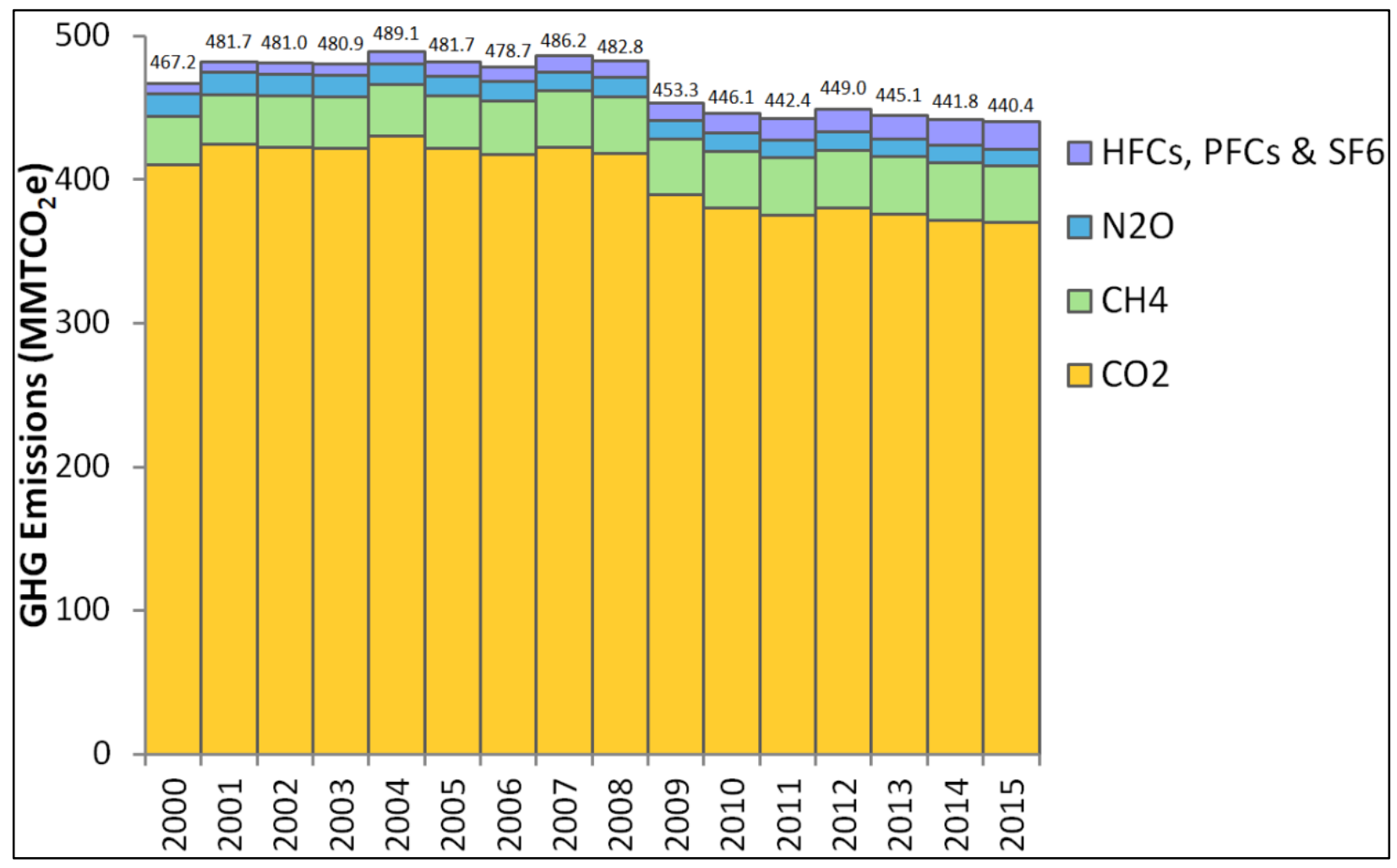

Figure 2:Bar chart of 2000 to 2015 GHG emissions by greenhouse gas

Courtesy of California Air Resources Board (CARB)

\section{Environmental Justice}

Environmental justice concerns have been one of the program's biggest sources of criticism. The 2012 failed lawsuit by activists remained a topic of consideration despite being legally defeated. Assembly member Cristina Garcia, chair of the Committee on Natural Resources, fought hard for better focus on local air quality and environmentally disadvantaged communities. She introduced assembly bill (AB) 378 which incorporated this focus into the extension of the cap-and-trade program. Heavy lobbying by Chevron was one of the main reasons her bill did not pass. The 17 Democrats who argued against Garcia's legislation received \$1.2 million in campaign donations from oil, gas, and labor (Mulkern, 2017). The fossil fuel 
industry has a seemingly enormous influence on moderate democrats because of their economic position. The cap-and-trade program was ultimately extended by AB 398 and supported by Garcia, but she continues to advocate for stricter protections for marginalized communities beyond the required $25 \%$ investment of revenue.

\section{Future Considerations}

Carbon pricing policies have the aim of reducing greenhouse gas emissions quickly. The data I reviewed seems to suggest that the California cap-and-trade program has yet to prove itself as a sturdy mechanism to reduce emissions. It does, however, create much needed revenue to invest in a clean energy future. Perhaps the most important result of the program is inspiring both state and global climate action. The Global Warming Solutions Act was a direct response to the failure of the United States to ratify the Kyoto Protocol. It also sent a message, worldwide, that California, the $6^{\text {th }}$ largest economy in the world, is committed to doing their part to reduce global warming. Reducing the number of allocated permits will, presumably, increase the demand and the price. Both of these will likely result in further emission reductions because it essentially increases the cost of polluting. I believe this is one of the best ways that the program can improve its performance. Additionally, more thought must be put into the relationship between cap-and-trade and other regulations so that one does not undermine the other.

\section{Pending Carbon Legislation in Oregon}

According to estimates by the Oregon Department of Environmental Quality, in 2015 statewide greenhouse gas emissions totaled 63 MMTCO2eq (DEQ, 2018). In comparison, the statewide greenhouse gas emissions in California totaled 440.4 MMTCO2eq (CARB, 201. While the carbon impact of Oregon is much less than that of California, climate change affects the 
entire globe. As articulated earlier in this paper, the lack of stringent emission thresholds across the United States makes emission reductions on the state level of great importance. Following President Trump's decision to withdraw from the Paris Agreement, Oregon Governor Kate Brown vowed to remain committed to the goals of the agreement (Pair, 2017). In order to meet the goals of the Paris Agreement, Oregon needs to enact competitive climate policy.

Fortunately, Oregon has many environmental organizations dedicated to protecting Oregonians from the effects of climate change. One of the most active organizations is Renew Oregon, a clean energy advocacy coalition. According to their website, Renew Oregon is "composed of businesses and workers, healthcare professionals, parents, farmers and ranchers, faith and community organizers, and individuals coming together to move our state away from polluting energy to a clean energy economy" (Renew Oregon, 2018). The coalition's primary goals are to, "create well-paying jobs that are safe and non-environmentally damaging, protect air and water from pollution and help families stay healthy."

In 2016, Renew Oregon passed the Clean Electricity and Coal Transition bill. The bill mandates Oregon's two largest utilities be off coal-fired electricity by 2030 and requires them to generate 50\% of their electric from renewable energy sources by 2040 (Renew Oregon, 2017). These requirements support Oregon's greenhouse gas reduction goal of 75\% below 1990 levels by 2050 (DEQ, 2018). In order to ensure a smooth transition, the bill includes a number of support systems. To encourage utilities to make early investments in renewable energy, the program provides incentives and requires utilities to incorporate community-scale renewable projects into their portfolios which creates Oregon clean energy jobs.

In 2017, the coalition introduced the Clean Energy Jobs bill, a cap-and-trade program, which is currently pending in the Oregon State Legislature. Similar to the California program, it 
impacts facilities that emit over 25,000 MTCO2eq on an annual basis. The revenue generated from the cap-and-trade program for this bill will go in to an investment fund. Due to a law in Oregon's constitution, $40 \%$ of the revenue is reserved for the highway trust fund. Renew Oregon, the coalition working to pass the bill, drafted language that advises how the state spend these funds, prioritizing infrastructure creation for electric vehicles and solar panels along the freeway to power lights and rest-stop areas. The remaining $60 \%$ of revenue invests in marginalized communities and clean energy solutions for the region. Renew Oregon's website states, "equity and a just transition to clean energy are central to the policy." It also cites that the energy solutions the program will invest in are, "affordable solar, energy efficiency upgrades to homes and businesses, more transportation options, and job training programs" and that, "investment will be targeted to rural communities for projects like wildfire prevention, drought protection and clean energy" (Renew Oregon, 2018). The Clean Energy Jobs bill did not pass in the 2018 legislative session but is expected to pass in 2019 and has the support of Oregon Governor Brown.

\section{Conclusion}

Market-based solutions are one of the most powerful tools to reduce greenhouse gas emissions and create revenue that can be invested in a clean energy future. In this paper, I explored California's cap-and-trade program. I discussed the need for strong climate policy in the United States and emphasized its urgency given our current set of environmental issues. A brief history of the international efforts to address climate issues leading up to the California Global Warming Solutions Act (AB 32) in 2006 which established a cap-and-trade program. I provided an overview of the general model of cap-and-trade programs and detailed which facilities are impacted, the level of the emissions cap, and the gases regulated under the bill. I 
then specified the features of the bill including the flexibility mechanisms, carbon permit trading, and how auction revenue is being used. I also reviewed the major concerns of the program including legal, market, renewable portfolio standards, emission reduction and environmental justice. I proposed future considerations to improve the program and gave a brief argument for continuing the program. Lastly, I provided information on the pending carbon legislation in Oregon. Future generations will reflect on this period of time in human history either inspired by bold action, or sorely disappointed that legislators did not protect their future. It is imperative that there be good faith efforts between government and industry to address the climate crisis so that future generations may enjoy their right to life, liberty, and the pursuit of happiness. 


\section{Works Cited}

Ashton, A. (2017, January 24). Is it a fee or tax? California's cap-and-trade faces tough questions. The Sacramento Bee. Retrieved from http://www.sacbee.com/news/politicsgovernment/capitol-alert/article128494604.html

California Court of Appeal. (2012, June 09). Association of Irritated Residents v. California Air Resources Board. Retrieved June 10, 2018, from http://climatecasechart.com/case/assocof-irritated-residents-v-cal-air-resources-board/

Center for Climate and Energy Solutions (C2ES). (2017, November 02). Policy Hub: California Cap-and-Trade. Retrieved December 06, 2017, from https://www.c2es.org/content/california-cap-and-trade/

California Environmental Protection Agency Air Resources Board (CARB). (September 2016). California Climate Investments from the Greenhouse Gas Reduction Fund. Available at https://www.arb.ca.gov/cc/capandtrade/auctionproceeds/final_expenditure_table_revised _10-6.pdf (last visited Dec 1, 2017).

Environmental Protection Agency (EPA). (2016, September 29). Overview of Climate Change Science. Retrieved December 01, 2017, from https://www.epa.gov/climate-changescience/overview-climate-change-science

International Energy Agency. (n.d.). Climate change. Retrieved December 01, 2017, from https://www.iea.org/topics/climatechange/

IPCC, 2013: Climate Change 2013: The Physical Science Basis. Contribution of Working Group I to the Fifth Assessment Report of the Intergovernmental Panel on Climate Change [Stocker, T.F., D. Qin, G.-K. Plattner, M. Tignor, S.K. Allen, J. Boschung, A. Nauels, Y. Xia, V. Bex and P.M. Midgley (eds.)]. Cambridge University Press, Cambridge, United Kingdom and New York, NY, USA, 1535 pp, doi:10.1017/CBO9781107415324. 
Kitson, L., P. Wooders and T. Moerenhout. (2011). Subsidies and External Costs in Electric Power Generation: A Comparative Review of Estimates. International Institute for Sustainable Development

Liptak, K., \& Acosta, J. (2017, June 02). Trump on Paris accord: 'We're getting out'. Retrieved December 01, 2017, from http://www.cnn.com/2017/06/01/politics/trump-paris-climatedecision/index.html

Megerian, C. (2017, April 06). California's cap-and-trade program survives a legal battle in a win for Gov. Jerry Brown and environmentalists. Retrieved April 25, 2018, from http://www.latimes.com/politics/la-pol-sac-california-cap-trade-decision-20170406story.html

Oregon Department of Environmental Quality (DEQ). (2018, May). Oregon's Greenhouse Gas Emissions through 2015. Retrieved June 10, 2018, from https://www.oregon.gov/deq/aq/programs/Pages/GHG-Inventory.aspx

Pair, C., \& Hockaday, B. (2017, June 02). Governor Kate Brown Announces Commitment to Goals of the Paris Agreement. Retrieved May 20, 2018, from http://www.oregon.gov/newsroom/Pages/NewsDetail.aspx?newsid=2091

Protecting the Environment and Promoting Clean Energy. (n.d.). Retrieved December 01, 2017, from http://www.schwarzenegger.com/issues/milestone/protecting-the-environment-andpromoting-clean-energy

Renew Oregon. (2018). Clean Energy Jobs. Retrieved May 20, 2018, from http://www.reneworegon.org/clean_energy_jobs

Renew Oregon. (2017). Coal to Clean Energy. Retrieved May 20, 2018, from http://www.reneworegon.org/coal to clean energy 
Takade, P. (2013). Association of Irritated Residents v. California Air Resources Board: Climate Change and Environmental Justice. Ecology Law Quarterly, 40(2), 573-582.

Templeton, M. (2016, September 30). The Clean Power Plan's Courtroom Battle -- How Much Does It Matter? Retrieved February 01, 2017, from http://www.forbes.com/sites/ucenergy/2016/09/30/the-clean-power-plans-courtroombattle-how-much-does-it-matter/print/

Trump, D. (2017, June 1). Statement by President Trump on the Paris Climate Accord. Retrieved May 06, 2018, from https://www.whitehouse.gov/briefings-statements/statementpresident-trump-paris-climate-accord/

Vartabedian, C. M. (2016, June 14). California's cap-and-trade program faces daunting hurdles to avoid collapse. Retrieved December 01, 2017, from http://www.latimes.com/politics/lapol-sac-climate-change-challenges-20160614-snap-story.html 